поглядів на світ його професії, яка динамічно розвивається, її роль і місце в соціумі, що визначають його ставлення до сфери міжкультурної, іншомовної і міжособистісної комунікації і до самого себе як суб’єкта педагогічної діяльності, а також зумовлена цими поглядами сукупність професійних переконань, ідеалів, принципів пізнання і дій, в основу яких покладено художньо-естетичний смак і педагогічну майстерність, соціальну зрілість і відповідальність кваліфікованого фахівця.

Професійний світогляд викладача зарубіжної літератури - це вищий синтез його професійних знань, емоційно-ціннісних оцінок і практичного досвіду щодо реалізації літературознавчої й педагогічної компетентностей. На цій основі, виходячи зі специфіки професійної праці викладача зарубіжної літератури й вимог до його особистості як особливого типу фахівця-професіонала, ми обгрунтувати структуру його професійного світогляду у складі інтелектуального, емоційно-ціннісного і діяльнісно-практичного компонентів, що тісно взаємодіють між собою, утворюючи цілісну систему. Крім того, упродовж формувального експерименту, проведеного на базі факультету романогерманської філології ОНУ ім. І. І. Мечникова впродовж 2008-2012 рр. було доведено, що формування професійного світогляду майбутнього викладача зарубіжної літератури відбуватиметься ефективніше за таких дидактичних умов, як-от: використання комплексу методів структуризації, систематизації та інтеграції культурологічних, поліхудожніх та історико-педагогічних знань студентів задля формування в них цілісної художньої та педагогічної картини світу; застосування психотехнічних та соціоігрових методів навчання фахових дисциплін задля актуалізації художньо-смислової рефлексії студентів та концептуалізації їх емоційно-ціннісного ставлення до творів зарубіжної літератури як складника педагогічної культури; моделювання ситуацій діалогізації професійнопедагогічного спілкування, що враховують плюралістичний характер європейського та світового освітнього простору.

Отже, у процесі власних спостережень за прикінцевими результатами професійної підготовки майбутнього викладача зарубіжної літератури ми дійшли висновку, що його професійний світогляд, будучи складноструктурованим новотвором його особистості як фахівця, разом з компонентною структурою має свій особливий функціональний механізм, що дозволяє не тільки диференціювати його сутність, але й забезпечувати автономність за допомогою реалізації сукупності відповідних функцій: просвітницької, розвивальної, виховної, прогностичної, організаційної, культурологічної. Перспективи подальшого дослідження проблеми вбачаємо в розробленні оновленого змісту світоглядної підготовки майбутніх викладачів зарубіжної літератури.

\title{
Література
}

1. Баталов А. А. Профессиональное мышление: Методологический аспект / А. А. Баталов. - М. : Наука, 1988. - 127 с. 2. Мировоззренческая культура личности: философские проблемы формирования / отв. ред. В. П. Иванов. - К. : Наук. думка, 1986. - 292 с. 3. Макарова Л. Н. Преподаватель высшей школы: индивидуальность, стиль, деятельность: [монография]: [в 2 ч.] / Л. Н. Макарова. - Тамбов : Изд-во ТГУ, 2000. Ч. 2. - 2000. - 142 с. 4. Цокур О. С. Категорія педагогічної свідомості у професійній підготовці майбутнього вчителя: дис. ... док. пед. наук: 13.00.01; 13.00 .04 / Ольга Степанівна Цокур. Одеса, 1998. - 397 с.

УДК 371. 134-057.875:81’243

I. В. Ромащенко, кандидат пед. наук, доцент, Академія муніщипального управління (м. Київ)

\section{ПРОФЕСІЙНА КУЛЬТУРА ВИКЛАДАЧА ЯК УМОВА САМОРЕАЛІЗАЦІЇ ПЕДАГОГА}

Ромащенко І. В. Професійна культура викладача як умова самореалізації педагога.

У статті доведено актуальність питання культури професійного спілкування викладача, сформульовано основні вимоги до професійного мовлення на сучасному етапі. Автором визначена 
головна ідея професійного спілкування у процесі навчання, обгрунтовано необхідність досконалого професійного спілкування, тактовності та культури мовлення у професійній діяльності викладача сучасного ВНЗ.

Ключові слова: комунікативність, комунікативна компетентність, професійне спілкування, мовна освіта, пріоритетні завдання, комунікативні якості.

Ромащенко И. В. Профессиональная культура преподавателя как условие самореализации педагога.

В статье рассматривается актуальность вопроса культуры профессионального общения преподавателя, сформулированы основные требования к профессиональной речи на современном этапе. Автором определена главная идея профессионального общения в процессе обучения, обоснована необходимость совершенного профессионального общения, тактичности и культуры речи в профессиональной деятельности преподавателя современного вуза.

Ключевые слова: коммуникативность, коммуникативная компетенция, профессиональное общение, языковое образование, приоритетные задачи, коммуникативные качества.

Romashchenko I. V. Professional culture of teacher as a condition of self-actualization of educator.

The thesis is concerned with the problem of future tearchers communicative skills as the main sourse of instolation Europinian standarts in studing and teaching process of modern education. The theoretical analysis of the research problem from the point to Psychology and Pedagogy is made. The main approaches to the definition of the term «communication» and «communicative skills» are written. Sufficient pedagogical conditions and methods for forming communicative skills are defined by the author.

Key words: communication, communicative competence, communicative skills, main tasks of priorities.

Здобуття вищої освіти - одна з головних загальнолюдських цінностей. В умовах демократизації суспільства і посиленої уваги до формування особистості стрімкий розвиток і постійне впровадження інноваційних технологій потребують створення сприятливих умов для отримання вищої освіти: нові підходи до розроблення методологічних основ забезпечення якості освітньої діяльності; належне інформаційне i комп'ютерне забезпечення навчального процесу ВН3 України; координація i прогнозування обсягів державного замовлення на підготовку фахівців певної галузі знань 3 урахуванням потреб ринку праці; високий професіоналізм науково-педагогічних працівників та науково-дослідницьке спрямування їхньої діяльності та сприяння запровадженню європейських стандартів вищої освіти в Україні. Серед зазначених чинників належне місце посідає проблема формування культури педагогічної діяльності викладача. Стрімкі процеси інтеграції України у європейське та світове співтовариство зумовлюють об'єктивне зростання попиту на викладачів високого фахового рівня та культури, які здатні ефективно реалізувати комунікативні наміри, оскільки суспільство декларує викладача ВНЗ як високосвічену особистість з певним рівнем культури думки, культури праці й культури мовлення.

Питання реалізації творчого потенціалу викладача досліджувалося Ю. Бабанським, С. Сисоєвою, М. Никандровим та іншими. Культура мовлення майбутнього фахівця вивчається зарубіжними (К. Брамфіт, М. Кенел та М. Свейн, І. Бім, Н. Гез, І. Зимня та ін.) і вітчизняними (Н. Бичковою, І. Воробйовою, С. Срмоленко, Н. Дзюбишиною-Мельник, Л. Пустовіт, Н. Сологуб, Л. Ставицькою, С. Ніколаєвою, О. Петращук, В. Топаловою, В. Русанівським та ін.) дослідниками.

Meта статmi - довести, що професійна культура викладача є запорукою успішного та результативного навчального процесу.

Отримуючи вищу освіту, людина свідомо чи несвідомо готує себе до майбутньої управлінської діяльності в галузі певної професійної спеціалізації. У процесі діяльності відбувається інтеграція морального, правового, економічного, соціального та психологічного аспектів відповідальності у професійній діяльності управлінця, яка $\epsilon$ 
мірою усвідомлення особистістю своїх професійних обов'язків [12]. В умовах глибоких політичних, економічних та соціокультурних змін, реформування системи освіти України, відповідно до потреб інтеграції у світовий освітній простір, приєднання до Болонського процесу, культура професійного мислення і спілкування викладача, його особистісний розвиток набувають особливого значення. Формування викладача як професіонала, виховання активної життєвої позиції визначено пріоритетними завданнями «Національної доктрини розвитку освіти України в XXI столітті», законах України «Про освіту», «Про вищу освіту». В умовах світової глобалізації, інформатизації ринкових відносин, у яких надзвичайно важливими $є$ професійність і конкурентоспроможність особистості, головним капіталом фахівця є його компетентність та професійна кваліфікація. Освітня система покликана виконувати запити суспільства. Успішна реалізація поставлених завдань перед будь-яким освітнім закладом можлива лише за умови високого рівня організації навчального процесу та високого професіоналізму педагогічних кадрів. Якісна освіта індикатор життя високого рівня. Отже, висококваліфікований викладач повинен бути професіоналом, мати педагогічне покликання, прагнення до постійної самоосвіти та вміння спілкуватися. Культура спілкування - це синтез високого професіоналізму i духовно-ціннісних якостей педагога, міра творчого засвоєння накопиченого людством світового культурно-історичного досвіду, оволодіння гуманістичними технологіями i наявність культуротворчих здібностей [1]. Термін «мовна освіта», професійне спілкування, має практичне спрямування, використання якого передбачає розвиток усного та писемного мовлення, формування комунікативної компетенції [3]. У наукових джерелах комунікативна компетенція тлумачиться як здатність спілкуватися 3 метою обміну інформацією, здатність користуватися мовою залежно від професійної ситуації і професійного наміру [10].

На думку Н. Бутенко, основним принципом педагогічного спілкування на сучасному етапі є суб'єкт-суб'єктний характер, що полягає в рівності позицій, гуманістичній настанові, активності суб'єктів навчального процесу, взаємопроникненні у світ почуттів та переживань, готовності сприйняття співрозмовника [5]. У психологічному словнику поняття «спілкування» трактується як складний, багатоплановий процес встановлення і розвитку контактів між людьми, що виникає на основі потреб і спільної діяльності та включає обмін інформацією, сприймання і розуміння іншого; це взаємодія суб'єктів за допомогою знакових засобів, викликана потребами спільної діяльності та спрямована на значущі зміни стану, поведінки партнера [9].

Професійне спілкування - це володіння мовними засобами, дотримання мовленнєвих норм, уміння будувати тексти, уникати мовних штампів, володіння мовним етикетом, доцільне використання професійної лексики, уміння здійснювати постійний аналіз ефективності професійної комунікації. В. Сухомлинський зазначає, що проголошуючи думку «культура мови - загальна культура людини», маємо дбати про такі моральноетичні категорії, як любов до рідної мови, мовно-національна свідомість, які стають реальністю тільки за активного ставлення до слова, коли існує постійна потреба шліфувати свою мову, вчитися слухати й сприймати слово, володіти ним як засобом вираження думки. У мові людини віддзеркалюється їі освіченість, бо мова - це й характер мислення, і здатність діяти, створювати щось нове. У результаті навчання студентивикладачі повинні реалізувати комунікативний намір адекватно завданню та умовам спілкування - переконати; забезпечити зв'язність та цілісність висловлювання; наводити аргументи і докази, висловлювати свою точку зору; використовувати різноманітні мовленнєві зразки. Оскільки, як стверджував В. Сухомлинський, «виховуємо ми не тільки ідеями, закладеними у знаннях, які ми передаємо учням, але насамперед тим, як ці знання і закладені в них ідеї несемо в клас ми, живі люди, тим, що людина доторкається до людини, до іï душі своєю душею» [11]. Отже, комунікативна компетентність майбутнього викладача розуміється як інтегральна якість особистості, яка синтезує в собі загальну культуру спілкування та їі специфічні вияви у професійній діяльності. Адже саме засоби 
живого переконливого слова забезпечують формування творчої особистості учня чи студента. Характер мовленнєвої діяльності викладача, його стиль спілкування, - це один із ключових аспектів його професійного впливу на суб'єкт навчального процесу.

Формування комунікативної компетенції викладачів має забезпечуватися комплексом дисциплін психолого-педагогічного та філологічного циклів. На розвиток комунікативної компетенції мають бути зорієнтовані всі форми навчальної роботи у вищій школі (лекції, практичні, індивідуальні, семінарські заняття тощо), оскільки комунікативні вміння й навички реалізуються під час кожного виду мовленнєвої діяльності (аудіювання, читання, говоріння, письма) [4]. Головними особливостями технології формування комунікативної компетентності на сучасному етапі є: реальне використання мови відповідно до певного соціально спрямованого контексту; побудова навчального процесу вимагає залучення студентів до ситуативного спілкування, максимально наближеного до реальних ситуацій; змінюються функції викладача, який стає активним координатором навчальної діяльності студентів, їх радником, співрозмовником та учасником процесу навчання; урізноманітнюються види діяльності на практичних заняттях, перевага надається парним, груповим видам діяльності, рольовим іграм, діловим іграм, проектним завданням, завданням із розв'язанням певних проблем, діалогу, дискусії, дебатам, моделюванню ситуацій. Під час таких видів навчання студенти вчаться критично мислити, розв'язувати складні проблеми на основі аналізу обставин і відповідної інформації, порівнюючи альтернативні думки, приймати продумані рішення, брати участь у дискусії; змінюється ставлення викладача до можливих мовленнєвих помилок студентів, який не акцентує на них увагу. Помилка має право на існування, однак аналіз мовлення проводиться узагальнено, без називання автора помилок.

Науковці I. Колесникова, О. Долгіна підкреслюють, що комунікативний підхід спрямований на формування: діяльнісного характеру мовленнєвого спілкування, що забезпечується комунікативною поведінкою викладача як безпосереднього учасника процесу спілкування та навчання і комунікативно вмотивованою, активною поведінкою студента як суб'єкта спілкування та навчання; предметності процесу комунікації, яка має бути змодельована з урахуванням точно визначеного набору предметів обговорення (тем, проблемних ситуацій, подій тощо); мовленнєвих засобів, які забезпечують процес спілкування та навчання в певних ситуаціях.

Спілкування - передача і повідомлення інформації пізнавального характеру, обмін знаннями, навичками і вміннями в процесі мовленнєвої взаємодії двох або більше людей [7].

В.Черевко витлумачує «комунікативну компетентність» як інтегральну якість особистості, що синтезує в собі загальну культуру спілкування та їі специфічні вияви у професійній діяльності [13].

На переконання I. Воробйової, головна ідея комунікативного навчання - це спрямованість навчального процесу на формування та розвиток практичних умінь володіння мовою як засобом спілкування у відповідних життєвих ситуаціях, залежно від мети спілкування [6].

До комунікативних якостей викладача більшість науковців зараховують: емпатію і професійну рефлексію (А. Деркач); вміння вислухати (Т. Воропаєва); тактовність (М. Єрастов); справедливість, пильність, чуйність (В. Сластьонін); гнучкість і делікатність, спрямованість на відкрите й активне спілкування, здатність швидко встановлювати контакт (М. Галагузова); соціальну сміливість (В. Келасьєв), комунікабельність, толерантінсть (В. Кан-Калик).

Важливу роль у процесі мовлення відіграє інтонаційна виразність, яка об'єктивно виражає певні почуття мовця, його емоційний стан, ставлення до співрозмовника та до процесу спілкування. Саме інтонаційно оформлене мовлення посилює вплив на свідомість студента, активізує його навчальну діяльність. 
Формування культури професійного спілкування можливе за умови надання належної уваги мовному і мовленнєвому аспектам навчального процесу, розвитку умінь і навичок аргументації, переконання студентів в тому, що культура професійного спілкування - це невід'ємний чинник їхньої майбутньої успішності у професійній діяльності. Тому надзвичайно важливо приділяти достатню увагу формуванню функціональної грамотності, виробленню умінь побудови логічного висловлювання, закріпленню стійких навичок функціонально-правильного професійно-орієнтованого усного i писемного мовлення, постійної потреби в інтелектуальній взаємодії під час пошуку розв'язання проблемних ситуацій у навчальному процесі, створенню ситуацій успіху й емоційної підтримки, утвердженню гуманістичних цінностей. А це забезпечується підбором та постійним використанням відповідних емоційно забарвлених навчальних матеріалів, які б сприяли осмисленню моральних категорій, визначенню духовних пріоритетів, гуманному ставленню до співрозмовника (колеги по роботі, ділового партнера), вияву небайдужості до подій суспільного життя. Утілення в реальний навчальний процес зазначених нами підходів можливе лише за умови сприйняття викладачем своєї професійної діяльності як партнерської діяльності, реальної допомоги студентам в особистісному становленні й розвитку, тобто, за умови професійно-педагогічної спрямованості педагога, який не забуває, що: «Тільки в спілкуванні, у взаємодії людини з людиною розвивається «людина в людині» як для інших, так і для себе самої» [3]. Оптимально, якщо студентові цікаво працювати на занятті, він бере активну участь в обговоренні проблем, відчуває своє особистісне зростання.

Питання культури професійного спілкування набуває особливого значення в сучасних реаліях інформаційної доби, за якої спостерігаємо трансформаційні процеси в осмисленні світоглядних позицій. Ми погоджуємося з позицією науковця О. Шпака, який зауважує, що сьогодні всі розуміють, що багатство країни визначається сукупним рівнем інтелектуального потенціалу суспільства [14].

Отже, професійне спілкування викладача вищої школи - це педагогічні цінності, прагнення педагога до особистої самореалізації і професійного зростання, культура професійного мислення, творча педагогічна діяльність, висока пізнавальна активність, що сприяють формуванню інтелектуального потенціалу суспільства - випускника вищої школи.

Культура професійного спілкування забезпечує оптимальну соціалізацію студентської молоді в інформаційну добу, сприяє активному засвоєнню ними соціальних норм, цінностей, що поширюються інформаційними комунікаціями, перетворюючи їх на відповідну систему соціальних настанов, ціннісних орієнтацій, забезпечують гармонійне залучення молоді до реального активного суспільного життя та компетентної професійної діяльності.

\section{Література}

1. Ахудеева Л. А. Коммуникативная культура будущого учителя как объект системного исследования / Л. А. Ахудеева. - Казань: Изд-во Казанск. ун-та, 2006. - 164 с. 2. Бахтин М. Проблеми поэтики Достоевского / М. Бахтин. - М., 1963. - 430 с. 3. Білясв О. Концепція мовної освіти в Україні / О. Біляєв, М. Вашуленко, В. Плахотник // Рідна школа. - 1994.- №9. - С.71-73. 4. Босак Н. Ф. Формування комунікативної компетенції майбутніх словесників у циклі фахових дисциплін // Педагогічні науки : [зб. наук. праць]. Випуск 39 / Н. Ф. Босак, О. А. Копусь. - Херсон: Видавництво ХДУ, 2005.- С.193-196. 5. Бутенко Н. Ю. Комунікативні процеси у навчанні: [підручник] / Н. Ю. Бутенко. - К. : КНЕУ, 2006. - 346 с. 6. Воробйова І. А. Формування соціокультурної компетенції учнів старшої школи засобами іноземної мови: автореф. дис. на здобуття наук. ступеня канд. пед. наук: 13.00 .04 «Теорія і методика професійної освіти» / I. А. Воробйова / Інститут педагогіки АПН України. - К., 2003. - 20 с. 7. Колесникова И. Л. Англо-русский терминологический справочник по методике преподавания иностранных языков / И. Л. Долгина, И. А. Колесникова. - Cambridge University Press, 2001. - 224 c. 8. Потебня А. А. Мысль и язык / А. А. Потебня. - Х., 1913. - 154 с. 9. Психология. Словарь. - М., 1990. - 244 с. 10. Словник-довідник з української лінгводидактики: [навч. посібник] / за ред. М. Пентилюк. - К. : Ленвіт, 2003. - 149 с. 11. Сухомлинський В. О. Лист про 
педагогічну етику / В. О. Сухомлинський // Вибр. тв.: у 5 т. - К. : Рад.шк., 1977. - Т. 5. - С. 591-600. 12. Управлінські аспекти соціальної роботи: [курс лекцій] / за заг. ред. М. Ф. Головатого. - К. : МАУП, 2004. - 260 с. 13. Черевко В. П. Формування комунікативної компетентності майбутнього менеджера у процесі професійної підготовки: дис. ... канд. психол. наук : 19.00.07 / В. П. Черевко. - К., 2001. 247 с. 14. Шпак О. Економіка освіти - складова професіоналізму вчителя / О. Т. Шпак // Молодь і ринок. - 2010. - №1-2. - С.13-18.

УДК 371.132:372

B. В. Садова,

кандидат пед. наук, доиент,

Криворізький педагогічний інститут

ДВНЗ «Криворізький національний університет»

\section{ПРОЦЕСУАЛЬНІ АСПЕКТИ ФОРМУВАННЯ ІСТОРИКО-ПЕДАГОГІЧНОЇ КУЛЬТУРИ СТУДЕНТІВ}

Садова В. В. Процесуальні аспекти формування історико-педагогічної культури студентів.

Стаття містить теоретичне обгрунтування історико-педагогічної культури студентів як навчально-особистісного феномену; на грунті аналізу наукової літератури подається експлікація терміна «історико-педагогічна культура»; уточнюються процесуальні аспекти формування історико-педагогічної культури студентів у навчально-виховному середовищі філологічних факультетів.

Ключові слова: студенти педагогічного інституту, історико-педагогічна культура, майбутній учитель.

Садовая В. В. Процессуальные аспекты формирования историко-педагогической культуры студентов.

Статья содержит теоретическое обоснование историко-педагогической культуры студентов как учебно-личностного феномена; на основе анализа научной литературы подается экспликация термина «историко-педагогическая культура», уточняются процессуальные аспекты формирования историкопедагогической культуры студентов в учебной среде филологических факультетов.

Ключевые слова: студенты педагогического института, историко-педагогическая культура, будущий учитель.

Sadova V. V. Process aspects concerning formation of students' history-and- pedagogy culture.

The article deals with some theoretical foundations of students' history-and-pedagogy culture as an education-and-personality phenomenon; on the basis of science literature analysis the explication of the «history-and-pedagogy culture» term is presented; the process aspects concerning the formation of students' history-and-pedagogy culture in the educational field of philology faculties are detailed.

Key words: students of a pedagogical institute, history-and-pedagogy culture, future teacher.

«Однобічний спеціаліст є або брутальним емпіриком, або вуличним шарлатаном» [7, c. 156], - це зауваження видатного лікаря, педагога, суспільного діяча М. Пирогова, висловлене ним у середині XIX ст. на сторінках статті «Питання життя» (1856 р.) набуває неабиякої актуальності в перші десятиліття XXI століття. Наша доба є добою «вузької спеціалізації»: дуже часто спеціалісти, які здійснюють наукові розвідки, не обізнані 3 напрямами наукової роботи колег у межах одного навчального чи наукового закладу. Видатні науковці С. Капіца, С. Курдюмов, Г. Малинецький на прикладі природничих наук констатують: «... «фізик» на фізичних факультетах стає так багато (фізика напівпровідників, моря, землі, плазми, Сонця, елементарних часток тощо), що колеги зараз дуже приблизно уявляють і математичний апарат, і експериментальні методики, що використовуються на сусідній кафедрі» [4, с. 8]. I резюмують: не даремно Д. Менделєєв пропонував готувати спеціалістів 3 математики, хімії, фізики й біології на одному факультеті як засіб запобігання однобічної професійної чи наукової спрямованості. Історія наукових відкриттів XX ст. підтверджує справедливість цього твердження, адже сьогодні 